СТРУЧНИ ЧЛАНЦИ

PROFESSIONAL PAPERS

ПРОФЕССИОНАЛЬНЫЕ СТАТЬИ

\title{
CONTRIBUTION TO THE MODELING OF A PNEUMATIC SEMI-ACTIVE CONTROL OF VEHICLE SUSPENSION
}

\author{
Nabil S. Khettou ${ }^{a}$, Miroslav M. Demić ${ }^{b}$, \\ Slavko R. Muždeka ${ }^{a}$, Milan M.Krsmanovića \\ a University of Defense in Belgrade, Military Academy, \\ e-mail: nabil.khettou@hotmail.fr; slavko.muzdeka@gmail.com; \\ krsma@beotel.net \\ ${ }^{\mathrm{b}}$ Retired Professor, \\ e-mail: demic@kg.ac.rs
}

FIELD: Mechanical Engineering

DOI: $10.5937 /$ vojtehg63-7744 ARTICLE TYPE:Professional Paper ARTICLE LANGUAGE: English

\section{Abstract:}

This paper contributes to the modeling of a semi-active control of a quarter vehicle model using air springs. A conventional mass-spring-damper model has been used along with an air spring. Based on the theory of thermodynamics, the dynamic equation of the air springmodelwas established. The simulation model was implemented using MATLAB and the transfer functions with varying parameters were calculated. The simulation results show that air spring pressure, the valve diameter, the dumping coefficient and the mechanical stiffness affect the dynamic response of the system. A semi-active control methodology was then established by controlling the valve diameter using two declinations of an on-off logic switch based on the velocity of the suspended mass and the relative velocity at both ends of the air spring. The obtained results show reduced oscillation amplitudes around the natural frequency of the system.

Key words: air spring, suspension, pneumatic, vehicle.

\section{Introduction}

The automotive industry uses different kinds of suspension systems depending on costs, allowable space, kinematic properties and compliance attributes. The main purpose of a vehicle suspension system is to support 
the vehicle weight as well as to ensure a permanent liaison between the tires and the road,to minimize the relative displacement between the sprung and unsprung mass and to keep that displacement inthe range allowable by vehicle design (Hrovat, et al., 1988, pp.288-296).

Vehicle designers have given serious considerations to the suspension control system in order to enhance driving comfort, stability and road handling of the vehicle within the broad range of exploitation conditions. In fact, when accelerating, braking or bumping, high stiffness is required to minimize oscillations and enhance handling properties. When driving on a high category road, low stiffness is required for driving comfort (Karnopp, 2013, Gillespie, 1992).

These requirements cannot be achieved by passive suspension systems. Therefore, an increasing need has appeared over the last years for new suspension systems which can handle the broad range of driving conditions to improve driving comfort and handling properties. In the literature, these systems with controlled characteristics are called "active" and "semi-active" suspensions. Their classification can be found in (Wang, 2001), (Silani, 2004), (Robinson, 2012), and will not be given in this paper. In these new systems,air springs have found wide usein vehicle suspensions due to their key characteristic - they can change their dynamic stiffness depending on driving and road conditions.

The most commonly used vehicle models for research purposes are mainly quarter vehicle models (Sekulic, Dedovic, 2011, pp.231244).Higherprecision can be achieved using half (Abbas, et al., 2013, pp.199-205) and full models (Demic, et al., 2006, pp.145-158).

A semi active suspension is composed of a spring type element and an adjustable dumper along with a control strategy. Numerous control schemes can be found in the literature. A concept based on changing natural frequency of the air spring has been introduced in (Porumamilla, et al., 2008, p.31001). The method consists of changing the dumping ratio of the system air spring-accumulator by opening and closing the connecting valve but no control was used. In (Porumamilla, 2007) a mathematical model, similar to the one established in (Porumamilla, et al., 2008, p.31001) was used along with a sliding mode controller with reference to a skyhook. A logic switch method was used in (Demic, 2005)based on the control of the damping coefficient under certain conditions.

In this paper, a semi active suspension of a quarter vehicle model is analyzed, using the air spring dynamic model developed in (Robinson, 2012). Two versions of the on-off logic switch method were used to test the semi active control of the suspension. 


\section{Quarter vehicle suspension model}

The physical model of the quarter vehicle model is illustrated in Figure 1.The model consists of a mass supported by a spring type element, a damper, and an air spring, while the other ends are attached to the base. The reversible sleeve air spring is a rubber chamber with flexible walls which expands and retracts under pressure. The resulting vertical reaction of the spring that transmits directly to the mass support is expressed as:

$$
\mathrm{F}_{\mathrm{sp}}=\left(\mathrm{P}_{\mathrm{sp}}-\mathrm{P}_{\mathrm{sp} 0}\right) \cdot \mathrm{A}_{\mathrm{eff}}
$$

Where $A_{\text {eff }}$ is the effective area that supports the sprung mass, the function of the air spring height, $\mathrm{P}_{\mathrm{sp}}$ is the absolute pressure in the air spring, andP $\mathrm{P}_{\mathrm{sp} 0}$ is the absolute pressure in the air spring at equilibrium.

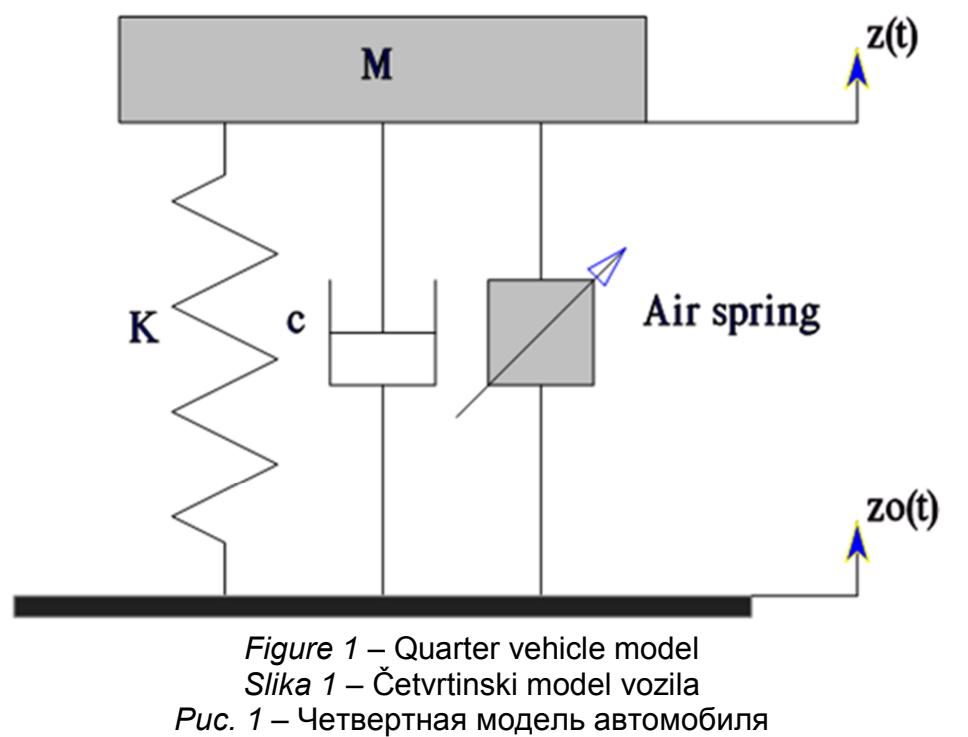

The mass $M$ shows a vertical bouncing motion. The motion is restricted to the vertical to the plan $\mathrm{e}_{1}, \mathrm{e}_{3}$. The system has one degree of freedom characterized by the generalized coordinate $\mathrm{z}(\mathrm{t})$. It describes the deviation of the vehicle body from its reference position which coincides with the equilibrium position att $=0(\mathrm{z}(\mathrm{t}=0)=\dot{\mathrm{z}}(\mathrm{t}=0)=(\ddot{\mathrm{z}}(\mathrm{t}=0)=0)$.

Using Newton's Second Law of Motion with the assumed coordinate direction shown in Figure 2, the force balance on the suspended mass reads as:

$$
M \ddot{z}(t)=-F_{k}-F_{c}-F_{s p}-M . g
$$


Therefore, $\dot{\mathrm{V}}_{\mathrm{sp}}$ can be expressed as:

$\dot{\mathrm{V}}_{\mathrm{sp}}=\left(\frac{\mathrm{dV} \mathrm{sp}}{\mathrm{dh}}\right) \cdot\left(\frac{\mathrm{dh}}{\mathrm{dt}}\right)=\mathrm{kh}$

Bearing in mind that the volume of the reservoir is constant, the differential equation governing the pressure in the reservoir is:

$$
\dot{P}_{r}=\frac{n R T_{r(e)}}{V_{r}}\left(\frac{P_{r}}{P_{r(e)}}\right)^{\frac{n-1}{n}} \cdot \dot{m}
$$

If the air spring oscillationsare considered isothermal, the dynamic equation of the reservoir would be:

$$
\dot{P}_{r}=\frac{n R T_{r(e)}}{V_{r}} \cdot \dot{m}
$$

The differential equations have the following initial conditions:

$$
P_{s p}(t=0)=P_{r}(t=0)=P_{s p(e)}
$$

Because of further projected research purposes, the air spring choice was made so that it can support the weight of a quarter heavy road vehicle (20 tons). The air spring chosen for the simulation is the Firestone 1T15M-2 air spring. The working parameters are resumed in Table 1, (Firstone, 2007, p.93).

Table 1 - Working parameters for the simulation Tabela 1 - Radniparametrizasimulaciju

Таблица 1 - Рабочие параметры для моделирования

\begin{tabular}{|c|c|c|c|c|c|c|c|c|}
\hline $\begin{array}{c}h_{e} \\
{[m]}\end{array}$ & $\begin{array}{c}A_{e f f 0} \\
{\left[m^{2}\right]}\end{array}$ & $\begin{array}{c}V_{s p(e)} \\
{\left[m^{3}\right]}\end{array}$ & $\begin{array}{c}V_{r} \\
{\left[m^{3}\right]}\end{array}$ & $\begin{array}{c}T_{e} \\
{[K]}\end{array}$ & $\begin{array}{c}C_{d} \\
{[-]}\end{array}$ & $\begin{array}{c}P_{s p(e)} \\
{\left[10^{5} \mathrm{~Pa}\right]}\end{array}$ & $\begin{array}{c}A_{e f f}(h) \\
{\left[m^{2}\right]}\end{array}$ & $\begin{array}{c}V_{s p}(h) \\
{\left[m^{3}\right]}\end{array}$ \\
\hline 0,24 & 0,0485 & 0,011 & 0,04 & 293 & 0,63 & $2-9$ & $-0,05 h+0,0573$ & $0,05 h-0,00156$ \\
\hline
\end{tabular}

\section{Dynamicequationofthevalve}

In general, the air flow through an orifice is a highlynonlinear process, depending on numerous parameters. An equation governing air flow through a restriction was developed in (Zheng, et al., nd) which distinguishes whether the flow is laminar or turbulent:

$$
\text { if } \frac{P_{d}}{P_{u}}>0.518
$$



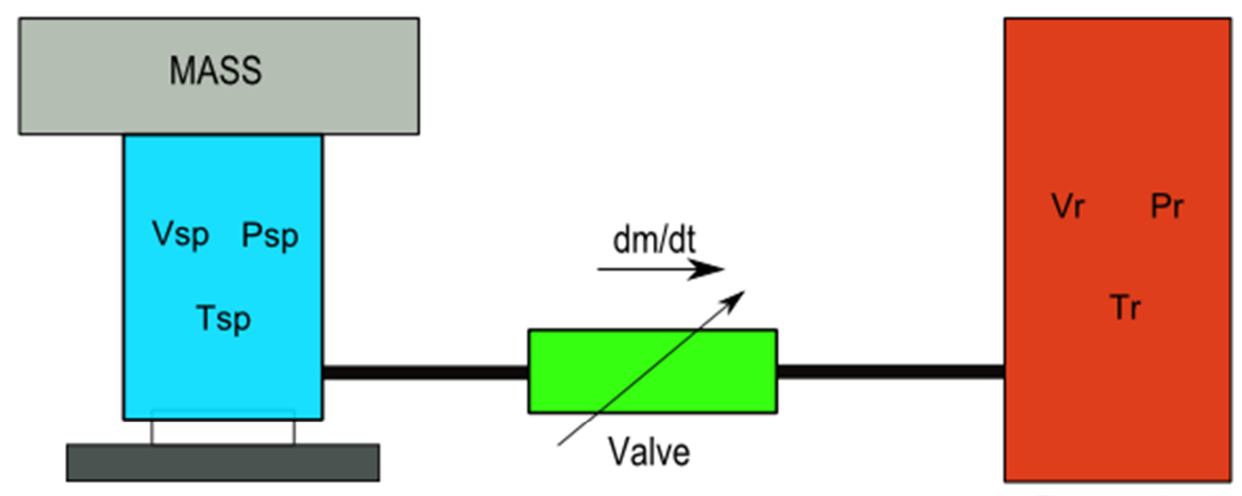

Air spring

Reservoir

Figure 3 - Physical model of the air spring Slika 3 - Fizički model vazdušne opruge

Puc. 3 - Физическаямодельпневматическойпружины

The pressure, volume and the density of air in the air spring are variable with the height of the air spring. Bear in mind the assumption that the air is an ideal gas, and that the air spring oscillation is regarded as an adiabatic process. The mass flow rate of air intothe air spring volume can be written as

Assuming an adiabatic transfer of the air, the relationship between the density and the volume of two different states can be expressed by

$$
\frac{\rho_{\mathrm{sp}}}{\rho_{\mathrm{sp}(\mathrm{e})}}=\left(\frac{\mathrm{P}_{\mathrm{sp}}}{\mathrm{P}_{\mathrm{sp}(\mathrm{e})}}\right)^{\frac{1}{\mathrm{n}}}
$$

\section{Where:}

$\rho_{\mathrm{sp}(\mathrm{e})}$ : air density at equilibrium;

$\mathrm{V}_{\mathrm{sp}(\mathrm{e})}$ : air volume spring at equilibrium;

$\mathrm{n}$ : air adiabatic exponent $(\mathrm{n}=1,4)$.

The ideal gas law at equilibrium can be expressed as

$\mathrm{P}_{\mathrm{sp}(\mathrm{e})} \mathrm{V}_{\mathrm{sp}(\mathrm{e})}=\mathrm{m}_{\mathrm{sp}(\mathrm{e})} \mathrm{RT}_{\mathrm{sp}(\mathrm{e})}$

Where:

$\mathrm{R}$ : is the air specific gas constant $\mathrm{R}=287,06 \mathrm{~J} \cdot \mathrm{Kg}^{-1} \cdot \mathrm{K}^{-1}$; 
$\mathrm{T}_{\mathrm{sp}(\mathrm{e})}$ : is the air temperature at equilibrium.

The air density at equilibrium is

$\rho_{\mathrm{sp}(\mathrm{e})}=\frac{\mathrm{m}_{\mathrm{sp}(\mathrm{e})}}{\mathrm{v}_{\mathrm{sp}(\mathrm{e})}}$

Replacing the expression of the mass of air at equilibrium in (10) leads to

$$
\rho_{\mathrm{sp}(\mathrm{e})}=\frac{\mathrm{P}_{\mathrm{sp}(\mathrm{e})}}{\mathrm{RT}_{\mathrm{sp}(\mathrm{e})}}
$$

Substituting (12) in (7) and differentiating with respect to timeproduces

$$
\dot{\rho}_{\mathrm{sp}}=\frac{\mathrm{P}_{\mathrm{sp}(\mathrm{e})}}{\mathrm{nRT}_{\mathrm{sp}(\mathrm{e})}}\left(\frac{\mathrm{P}_{\mathrm{sp}}}{\mathrm{P}_{\mathrm{sp}(\mathrm{e})}}\right)^{\frac{\mathrm{n}-1}{\mathrm{n}}} \cdot \dot{\mathrm{P}}_{\mathrm{sp}}
$$

Substituting (13) in (8) and rearranging the terms produces the firstorder differential equation for the air pressure in the air spring

$$
\dot{\mathrm{P}}_{\mathrm{sp}}=\frac{\mathrm{nRT}_{\mathrm{sp}(\mathrm{e})}}{\mathrm{V}_{\mathrm{sp}}}\left(\frac{\mathrm{P}_{\mathrm{sp}}}{\mathrm{P}_{\mathrm{sp}(\mathrm{e})}}\right)^{\frac{\mathrm{n}-1}{\mathrm{n}}} \cdot \dot{\mathrm{m}}+\frac{\mathrm{nP}_{\mathrm{sp}}}{\mathrm{V}_{\mathrm{sp}}} \dot{\mathrm{V}}_{\mathrm{sp}}
$$

If the air spring oscillations are to be assumed as isothermal, then therelationship between the density and the volume of two different stateswould be

$\frac{\rho_{\mathrm{sp}}}{\rho_{\mathrm{sp}(\mathrm{e})}}=\left(\frac{\mathrm{V}_{\mathrm{sp}}}{\mathrm{V}_{\mathrm{sp}(\mathrm{e})}}\right)$

In this case, the differential equation for the pressure is

$\dot{\mathrm{P}}_{\mathrm{sp}}=\frac{\mathrm{RT}_{\mathrm{sp}(\mathrm{e})}}{\mathrm{V}_{\mathrm{sp}}} \cdot \dot{\mathrm{m}}+\frac{\mathrm{P}_{\mathrm{sp}}}{\mathrm{V}_{\mathrm{sp}}} \dot{\mathrm{V}}_{\mathrm{sp}}$

The volumeV $_{\mathrm{sp}}$ needs to be determined. Previous research has suggested that, for engineering purposes, the volume can be assumed to be a function of height only without significant loss in accuracy (Quaglia, Sorli, 2001, pp.443-475). The relation between the volume and the air spring height will be determined using the dynamic chart provided by the manufacturers

$$
\mathrm{V}_{\mathrm{sp}}=\mathrm{V}_{\mathrm{sp}}(\mathrm{h})
$$


Therefore, $\dot{\mathrm{V}}_{\mathrm{sp}}$ can be expressed as:

$\dot{\mathrm{V}}_{\mathrm{sp}}=\left(\frac{\mathrm{dV} \mathrm{sp}}{\mathrm{dh}}\right) \cdot\left(\frac{\mathrm{dh}}{\mathrm{dt}}\right)=\mathrm{kh}$

Bearing in mind that the volume of the reservoir is constant, the differential equation governing the pressure in the reservoir is:

$$
\dot{P}_{r}=\frac{n R T_{r(e)}}{V_{r}}\left(\frac{P_{r}}{P_{r(e)}}\right)^{\frac{n-1}{n}} \cdot \dot{m}
$$

If the air spring oscillationsare considered isothermal, the dynamic equation of the reservoir would be:

$$
\dot{P}_{r}=\frac{n R T_{r(e)}}{V_{r}} \cdot \dot{m}
$$

The differential equations have the following initial conditions:

$$
P_{s p}(t=0)=P_{r}(t=0)=P_{s p(e)}
$$

Because of further projected research purposes, the air spring choice was made so that it can support the weight of a quarter heavy road vehicle (20 tons). The air spring chosen for the simulation is the Firestone 1T15M-2 air spring. The working parameters are resumed in Table 1, (Firstone, 2007, p.93).

Table 1 - Working parameters for the simulation Tabela 1 - Radniparametrizasimulaciju

Таблица 1 - Рабочие параметры для моделирования

\begin{tabular}{|c|c|c|c|c|c|c|c|c|}
\hline $\begin{array}{c}h_{e} \\
{[m]}\end{array}$ & $\begin{array}{c}A_{e f f 0} \\
{\left[m^{2}\right]}\end{array}$ & $\begin{array}{c}V_{s p(e)} \\
{\left[m^{3}\right]}\end{array}$ & $\begin{array}{c}V_{r} \\
{\left[m^{3}\right]}\end{array}$ & $\begin{array}{c}T_{e} \\
{[K]}\end{array}$ & $\begin{array}{c}C_{d} \\
{[-]}\end{array}$ & $\begin{array}{c}P_{s p(e)} \\
{\left[10^{5} \mathrm{~Pa}\right]}\end{array}$ & $\begin{array}{c}A_{e f f}(h) \\
{\left[\mathrm{m}^{2}\right]}\end{array}$ & $\begin{array}{c}V_{s p}(h) \\
{\left[\mathrm{m}^{3}\right]}\end{array}$ \\
\hline 0,24 & 0,0485 & 0,011 & 0,04 & 293 & 0,63 & $2-9$ & $-0,05 h+0,0573$ & $0,05 h-0,00156$ \\
\hline
\end{tabular}

\section{Dynamicequationofthevalve}

In general, the air flow through an orifice is a highlynonlinear process, depending on numerous parameters. An equation governing air flow through a restriction was developed in (Zheng, et al., nd) which distinguishes whether the flow is laminar or turbulent:

$$
\text { if } \frac{P_{d}}{P_{u}}>0.518
$$




$$
\dot{m}=C_{d} S P_{u} \sqrt{\frac{1}{R T_{e}} \frac{2 n}{n-1}\left[\left(\frac{P_{d}}{P_{u}}\right)^{\frac{2}{n}}-\left(\frac{P_{d}}{P_{u}}\right)^{\frac{n+1}{n}}\right]} \cdot \operatorname{sign}\left(P_{d}-P_{u}\right)
$$

if $\frac{P_{d}}{P_{u}} \leq 0.518$

$\dot{m}=C_{d} S P_{u}\left(\frac{2}{n+1}\right)^{\frac{1}{1-n}} \sqrt{\frac{2 n}{n+1} \frac{1}{R T_{e}}} \cdot \operatorname{sign}\left(P_{d}-P_{u}\right)$

Where

$\mathrm{P}_{\mathrm{u}}=\max \left(\mathrm{P}_{\mathrm{sp}}, \mathrm{P}_{\mathrm{r}}\right), \mathrm{P}_{\mathrm{d}}=\min \left(\mathrm{P}_{\mathrm{sp}}, \mathrm{P}_{\mathrm{r}}\right)$

$\mathrm{S}=\pi \frac{d^{2}}{4}$ is the area of the orifice.

$\mathrm{C}_{\mathrm{d}}$ is the coefficient of discharge of the orifice.

\section{Simulation results and discussion}

Because the dynamic model under study is nonlinear, it is quite difficult to solve the sets of differential equations (4), (14), (19) and (4), (16), (20) with analytical methods. The sets will be solved using numerical methods with a help of the MATLABsoftware package. The base excitation is set as a poly-harmonic function of ten harmonics with a frequency range from 0.5 to $30 \mathrm{~Hz}$ and anamplitude of $0.012 \mathrm{~m}$.

The paper analyses the effect of the spring stiffness, the shock absorber damping coefficient, the valve diameter, the air spring pressure as well as the air exchange process (adiabatic/ isothermal) on the transfer function of vertical displacement.

\section{Effect of the spring stiffness}

Calculating the transfer function of vertical displacement with varying mechanical stiffness showsthat the amplitude of vertical displacement decreases asthe spring stiffness increases for excitations frequencies below $1 \mathrm{~Hz}$ (Figure 4). For frequencies higher than $1 \mathrm{~Hz}$, suspension deformation increases as mechanical stiffness increases. On the abscise axis, the resonant frequency of the sprung mass grew slightly as mechanical stiffness increased. 

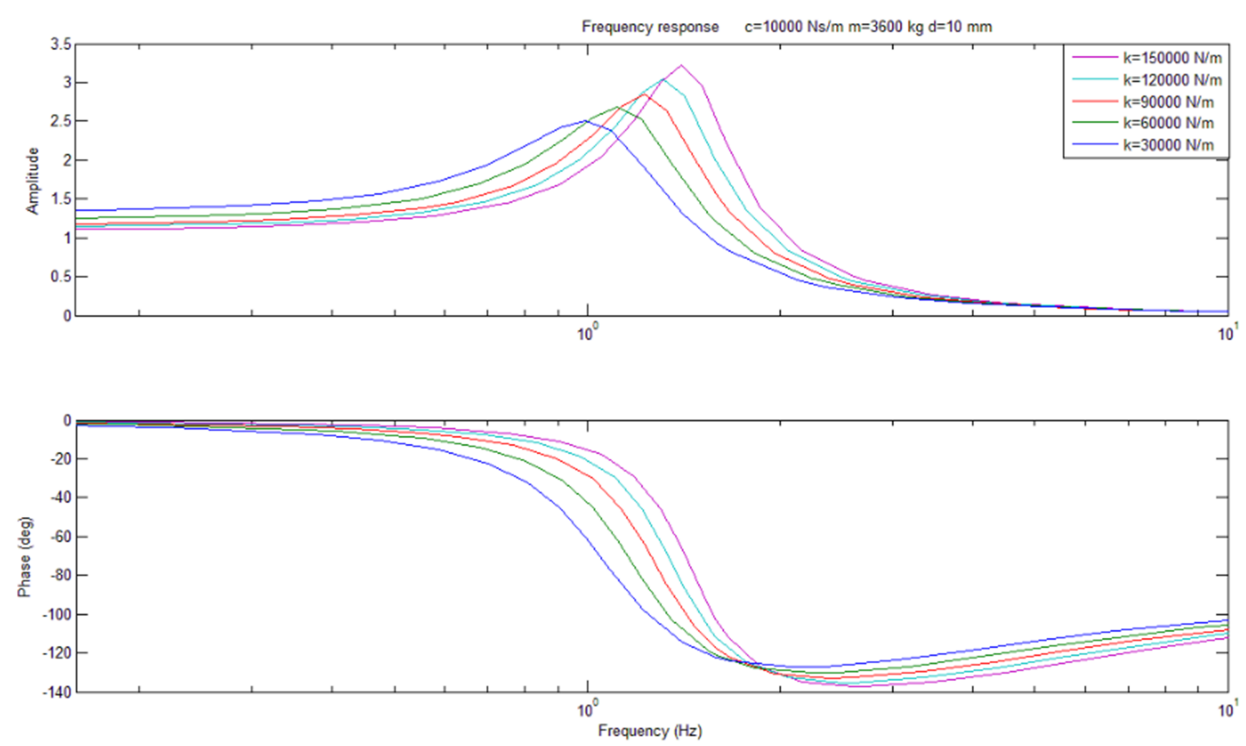

Figure 3 - Transfer function of vertical displacement for different values of spring stiffness Slika 4 - Prenosna funkcijavertikalnogpomeranjazarazličitevrednostikrutostiopruge Puc. 4 - Передаточная функция вертикального смещения при различных коэффициентахупругости пружины

\section{Effect of the shock absorber damping}

Figure 5 shows that the amplitude of vertical oscillations increases within the domain of resonant frequency as the damping coefficient increases. However, this increase didnot significantly affect the resonant frequency of the sprung mass (around $1.3 \mathrm{~Hz}$ ). Smaller damping coefficients ensure better oscillatory comfort for frequencies above the resonant frequency. 

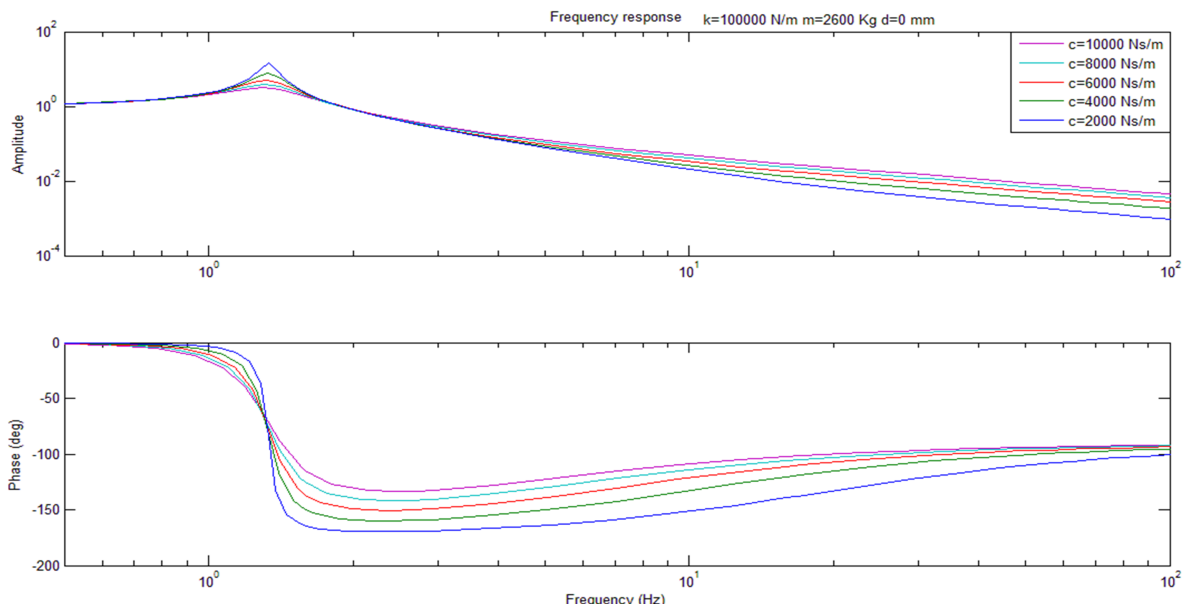

Figure 4 - Transfer function of vertical displacement for different damping values Slika 5 - Prenosna funkcija vertikalnog pomeranja za različite vrednosti prigušenja Puc. 5 - Передаточная функция вертикального смещения при различных коэфффициентах затухания

\section{Effect of the air spring pressure}

As shown in Figure 6, enhancing the static pressure in the air spring results in the increase of both the resonant frequency and the vertical amplitude. This behavior is similar to the effect of mechanical stiffness, which means that as the static pressure in the air spring increases, the dynamic stiffness of the air spring risesaround the resonant frequency and higher.
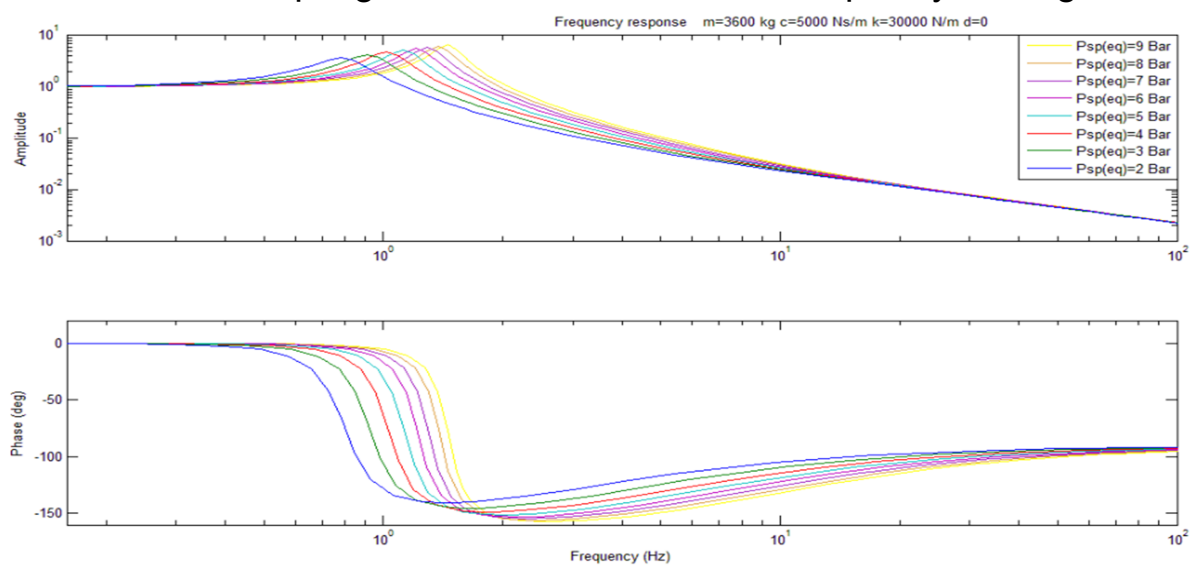

Figure 5-Transfer function of vertical displacement for different values of static pressure Slika 6 - Prenosna funkcija vertikalnog pomeranja za različite vrednosti statičkog pritiska Puc. 6 - Передаточная функция вертикального смещения при различных коэффрициентах статического давления 
However, for frequencies below the resonant frequency, higher pressures give a better oscillatory behavior. This behavior is similar to the effect of mechanical stiffness, which means that as the static pressure in the air spring increases, the dynamic stiffness of the air spring rises around the resonant frequency of the sprung mass and higher. However, for frequencies below the resonant frequency, higher pressures give a better oscillatory behavior.

\section{Effect of the air exchange process}
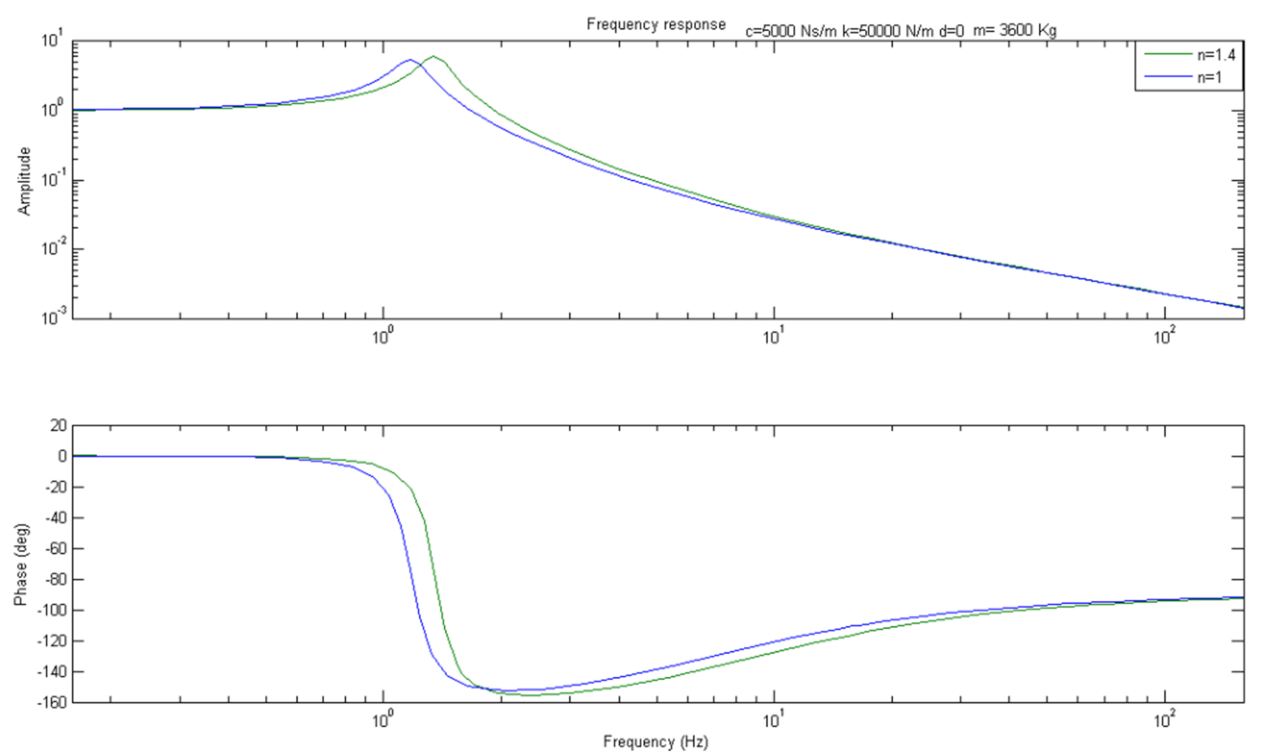

Figure 6-Transfer function of vertical displacement for the adiabatic/ isothermal exchange Slika 7 - Prenosna funkcija vertikalnog pomeranja za adijabatsku/izotermnu razmenu Puс. 7 - Передаточная функция вертикального сдвига при адиабатическом / изотермическом обмене

The air exchange process does not affect significantly the amplitude of oscillations of the sprung mass around the resonant frequency (Figure 7). However, at lower frequencies (below $1.3 \mathrm{~Hz}$ ), the adiabatic process $(n=1.4)$ ensuresa better oscillatory behavior. Above $1.3 \mathrm{~Hz}$, lower oscillation amplitudes were provided during the isothermal air exchange. 


\section{Effect of the valve diameter}

It can be concluded from Figure 8 that the valve connecting the air spring and the reservoir behaves like a dumper. In fact, the transfer functions in Figure 8 are analogous to those in Figure 5 which represent the effect of the shock damper coefficient.
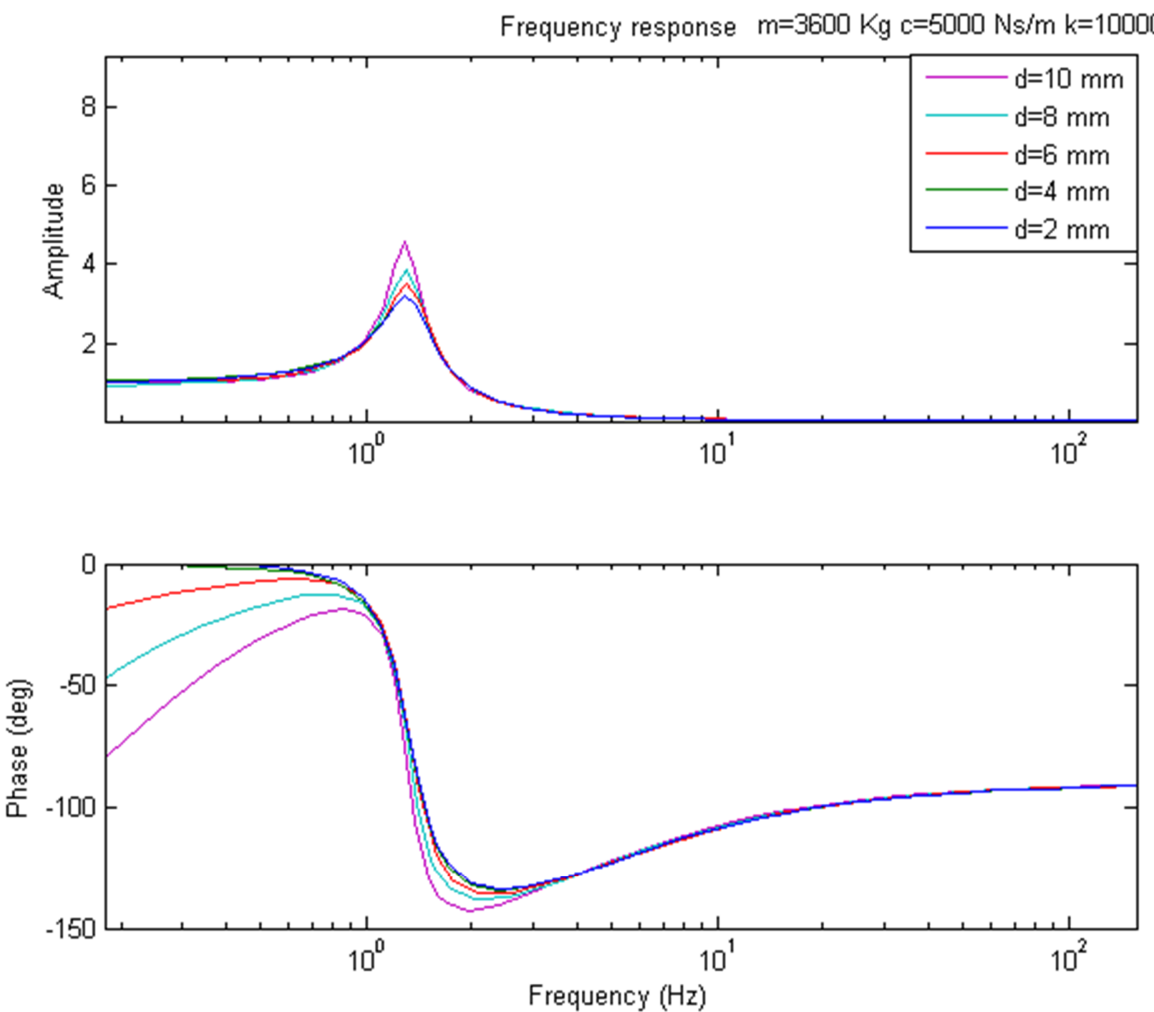

Figure 7 - Transfer function of vertical displacement for different valuesof the valve diameter Slika 8 - Prenosna funkcija vertikalnog pomeranja za različite vrednosti prečnika ventila

Puc. 8 - Передаточная функция вертикального смещения при различныхдиаметрах клапан

For frequencies close to the resonance frequency, the higher the valve diameter, the higher the oscillation amplitude. This can be explained by the fact that the smaller the diameter of the orifice is, the higher the resistance to air flow through the valve gets. This causes the orifice to dissipate more energy as the air flows back and forth between the air spring and the reservoir. 


\section{Control strategy}

The proposed control strategy is similar to the one used for semiactive dampers based on the measurement of relative velocity onthe both ends of the damper. The method consists of controlling the valve diameter of the air spring under certain conditions. In fact, when the velocities of the upper and the lower ends of the air spring (i.e. velocities of the sprung and the unsprung mass) have the same direction, the valve is set as fully opened. In the other case, the valve is set to closed. This strategy is called "Direct switching logic". Another version of this method will be tested by inverting the testing logic. When the velocities of the sprung and the unsprung mass have the same direction, the valve is set as closed. In the other case, it will be set as fully opened, hereafter referred to as "Inverted logic switch". In term of equations, we can write:

Direct switching: $\left\{\begin{array}{l}\text { if } \dot{z} \cdot\left(\dot{z}-\dot{z}_{0}\right)>0 \text { then } d_{\text {valve }}=d_{\text {max }} \\ \text { if } \dot{z} .\left(\dot{z}-\dot{z}_{0}\right) \leq 0 \text { then } d_{\text {valve }}=d_{\text {min }}\end{array}\right.$

$$
\text { Inverted switching: }\left\{\begin{array}{l}
\text { if } \dot{z} \cdot\left(\dot{z}-\dot{z}_{0}\right)>0 \text { then } d_{\text {valve }}=d_{\text {min }} \\
\text { if } \dot{z} .\left(\dot{z}-\dot{z}_{0}\right) \leq 0 \text { then } d_{\text {valve }}=d_{\text {max }}
\end{array}\right.
$$

\section{Results of the simulation and the discussion}

The simulation of the control strategy is held under the same conditions as in the previous simulation. Asit can be seen from Figure 9, the controlling method influences both the amplitude of oscillations and the resonant frequency of the system.In fact, the oscillation amplitude drops around and below the resonant frequency $(1.3 \mathrm{~Hz})$ when applying the direct logic switch. For frequencies higher than the resonant frequency, the two graphs tend to coincide with each other. For the inverted switch, the same behavior was observed but with a smaller amplitude. On the other hand, when applying both controllers, the resonant frequency moves to the right of the frequency axis. 

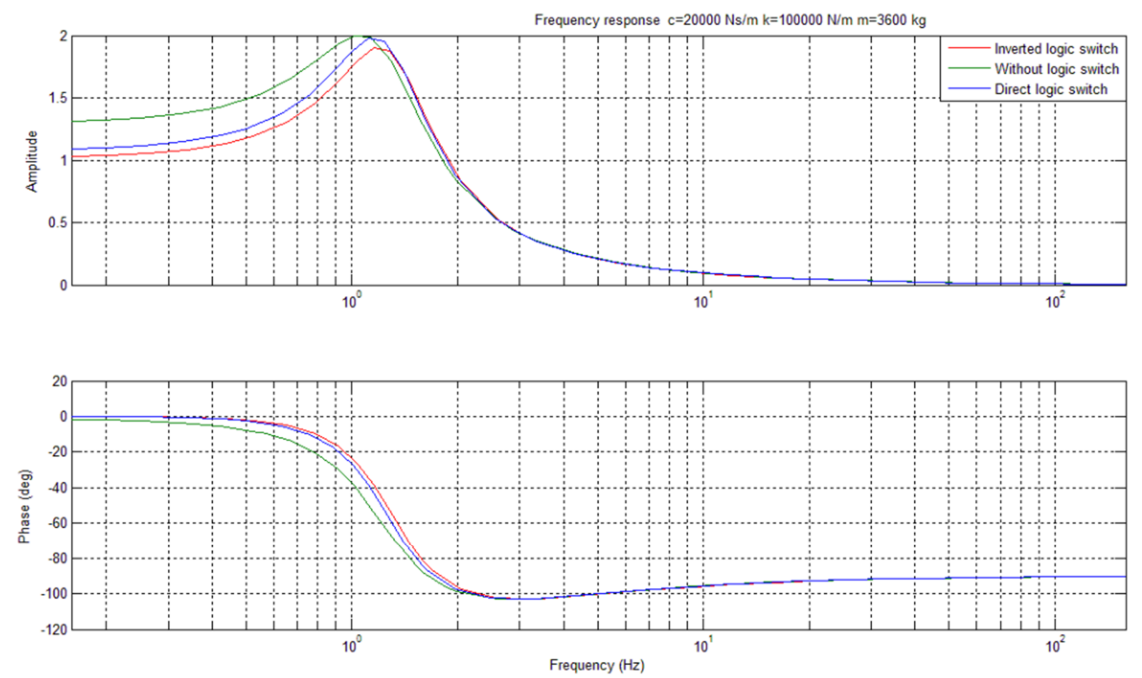

Figure 8 - Transfer function of vertical displacement with the logic switch controller Slika 9 - Penosna funkcija vertikalnog pomeranja s kontrolom logičkog prekidača Puc. 9 - Передаточная фрункция вертикального смещения, управляемая логическим контроллером

\section{Conclusion}

The results of the analysis presented in this paper have enabled us to consider the effect of the mechanical stiffness, the damping coefficient, the pressure in the air spring, the air exchange process as well as the valve diameter on the oscillatory behavior of a quarter vehicle model in the frequency domain. It has been observed that the change in the suspension parameters leads to the following conclusions:

- Amplitude of oscillations was reducedas mechanical stiffness was increased for excitation frequencies below $1.3 \mathrm{~Hz}$. Within the zone of the resonant frequency and higher, the oscillation amplitudes were increased as spring stiffness increased.

- Higher damping coefficients provided less important oscillations of the sprung mass at excitation frequencies close to the resonant frequency. At frequencies above $1.3 \mathrm{~Hz}$, a lower damping coefficient results in lower oscillation amplitudes.

- Air spring dynamic stiffness increases as static pressure rises. Higher pressures increase oscillations of the sprung mass around the resonant frequency and above it.

- The valve behaves as a shock damper. The smaller the diameter of the orifice, the higher the energy dissipation through the valve. 
- Lower exchange exponent (isothermal process) ensures lower oscillations at the excitation frequencies below the resonance. Above the resonant frequency, the adiabatic process provided lower vibration amplitudes.

The observed semi-active control strategies with the "on-off" switch improved thesuspension characteristics by reducing the amplitude of oscillations around and below the resonant frequency. The inverted logic switch provided the lowest amplitude. However,no significant effect was observed when applying the control strategy at higher frequencies.

\section{References}

Abbas, W., Emam, A., Badran, S., Shebl, M., \& Abouelatta, O. 2013. Optimal Seat and Suspension Design for a Half-Car with Driver Model Using Genetic Algorithm. Intelligent Control and Automation, 04(02), pp.199-205. doi:10.4236/ica.2013.42024.

Demic, M., Diligenski, D., \& Demic, I. 2005. A contribution to design of semi-active vehicle suspension system. . In: International Congress, Automotive and Environment, Pitesti, Romania. CAR20051013.

Demic, M., Dilligenski, D., \& Demic, I. 2006. A method of vehicle active suspension design. Forsch Ingenieurs, 70(3), pp.145-158. doi:10.1007/s10010-006-0025-5.

Firestone Industrial Products Company. 2007. Engineering Manuals \& Design Guide Metric, Indiana.

Gillespie, T.D. 1992. Fundamentals of Vehicle Dynamics.SAE. doi:10.4271/r-114.

Hrovat, D., Margolis, D.L., \& Hubbard, M. 1988. An Approach Toward the Optimal Semi-Active Suspension. Journal of Dynamic Systems, Measurement, and Control, 110(3), pp.288-296. doi:10.1115/1.3152684. Group.

Karnopp, D. 2013. Vehicle dynamics, stability, and control, 2nd ed.Taylor \& Francis

Porumamilla, H. 2007. Modeling, analysis and non-linear control of a novel pneumatic semi-active vibration isolator: A concept validation study. lowa State University.

Porumamilla, H., Kelkar, A.G., \& Vogel, J.M. 2008. Modeling and Verification of an Innovative Active Pneumatic Vibration Isolation System. Journal of Dynamic Systems, Measurement, and Control, 130(3), p.31001. doi:10.1115/1.2807049

Quaglia, G., \& Sorli, M. 2001. Air Suspension Dimensionless Analysis and Design

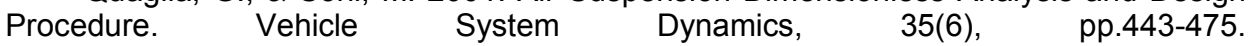
doi:10.1076/vesd.35.6.443.2040

Robinson, W.M. 2012. A pneumatic semi-active control methodology for vibration control of air spring based suspension systems. Iowa State University.

Sekulic, D., \& Dedovic, V. 2011. The effect of stiffness and damping of the suspension system elements on the optimisation of the vibrational behaviour of a bus. International Journal for Traffic and Transport Engineering, 1(4), pp.231-24

Wang, F.C. 2001. Design and Synthesis of Active and Passive Vehicle Suspensions. University of Cambridge, Department of Engineering.

Zheng, Z., \& Gu, R.. Light Industry Hydraulic and Pneumatic Transmission.Beijing, China: Light Industry Press. 
ВКЛАД В МОДЕЛИРОВАНИЕ УСТРОЙСТВА УПРАВЛЕНИЯ ПНЕВМАТИЧЕСКОЙ ПОЛУАКТИВНОЙ ПОДВЕСКОЙ ТРАНСПОРТНОГО СРЕДСТВА

Набил С. Кхеттоу ${ }^{\text {a }}$ Мирослав М. Демич ${ }^{6}$, Славко Р. Муждека ${ }^{a}$, Милан М. Крсманович ${ }^{a}$

а Университет обороны вг . Белград Военная академия

${ }^{\sigma}$ профрессор на пенсии

ОБЛАСТЬ: машиностроение

ВИДСТАТЬИ: профессиональная статья

ЯЗЫКСТАТЬИ: английский

Резюме:

В статье описано моделирование системы полуактивной пневматической подвески транспортного средства с применением четвертноймодели автомобиля. Рассматривалась подвеска традиционного типа (подрессоренная масса - массапружина-амортизатор) с применением пневматической пружины. Динамические уравнения пневматического упругого элемента выведены на основе законов термодинамики.Имитационная модель была разработана при использовании программного обеспечения MATLAB. B моделиприведены передаточные фрункции вертикального смещения подрессоренных масс с переменными параметрами.

Результаты моделирования показывают, что на динамические характеристики системы влияют следующие фракторы: давление в пневмокамере, диаметр клапана, коэфрфициент затухания и механическая жесткость пружины. Метод управления системой полуактивной подвески заключается в переменном диаметре клапана с использованием двухпозиционного переключателя, с учетом скорости смешения подрессоренных масс иотносительной скорости края пневмокамеры. Полученные результаты показывают, что примененные способ управления и конфигурация подвески обеспечивают снижение амплитуды колебаний подвески и равновесное положение системы.

Ключевые слова: пневматическая пружина, подвеска, пневматик, автомобиль.

\section{DOPRINOS MODELIRANJU PNEUMATSKOG POLUAKTIVNOG} UPRAVLJANJA SISTEMA OSLANJANJA VOZILA

Nabil S. Khettou ${ }^{a}$, Miroslav M. Demić ${ }^{b}$,

Slavko R. Muždeka ${ }^{a}$, Milan M. Krsmanovića

a Univerzitet odbrane u Beogradu, Vojna akademija

${ }^{b}$ penzionisani profesor 
OBLAST: mašinsko inženjerstvo

VRSTA ČLANKA: stručni članak

JEZIK ČLANKA: engleski

\section{Sažetak:}

$U$ radu je prikazano modeliranje poluaktivnog pneumatskog sistema elastičnog oslanjanja korišćenjem četvrtinskog modela vozila. Korišćen je konvencionalni model oslanjanja (ovešena masa - masaopruga-amortizer), u kombinaciji sa vazdušnom oprugom. Dinamičke jednačine pneumatskog elastičnog elementa izvedene su na osnovu zakona termodinamike. Simulacioni model razvijen je korišćenjem programskog paketa MATLAB. U modelu su date prenosne funkcije vertikalnih pomeranja ovešene mase sa promenljivim parametrima. Rezultati simulacije pokazuju da na dinamičko ponašanje sistema utiču pritisak u vazdušnom jastuku, prečnik ventila, koeficijent prigušenja $i$ mehanička krutost opruge. Metodologija poluaktivnog upravljanja sistemom oslanjanja zasniva se na kontroli prečnika ventila korišćenjem dva stanja jednog on-off prekidača, na osnovu brzine kretanja ovešene mase $i$ relativne brzine krajeva vazdušnog jastuka. Dobijeni rezultati pokazuju da usvojeni način upravljanja i konfiguracija sistema oslanjanja obezbeđuje smanjenje amplitude oscilacija oko ravnotežnog položaja sistema.

Ključne reči: vazdušna opruga, oslanjanje, pneumatici, vozilo.

Datum prijema članka/Paper received on / Дата получения работы: 17. 02. 2015. Datum dostavljanja ispravki rukopisa/Manuscript corrections submitted on / Дата получения исправленной версии работы: 12. 05. 2015.

Datum konačnog prihvatanja članka za objavljivanje/ Paper accepted for publishing on / Дата окончательного согласования работы: 14. 05. 2015.

(c) 2015 Autori. Objavio Vojnotehnički glasnik / Military Technical Courier (www.vtg.mod.gov.rs, втг.мо.упр.срб). Ovo je članak otvorenog pristupa i distribuira se u skladu sa Creative Commons licencom (http://creativecommons.org/licenses/by/3.0/rs/).

(C) 2015 The Authors. Published by Vojnotehnički glasnik / Military Technical Courier (www.vtg.mod.gov.rs, втг.мо.упр.срб). This article is an open access article distributed under the terms and conditions of the Creative Commons Attribution license (http://creativecommons.org/licenses/by/3.0/rs/).

( 2015 Авторы. Опубликовано в "Военно-технический вестник / Vojnotehnički glasnik / Military Technical Courier" (www.vtg.mod.gov.rs, втг.мо.упр.срб). Данная статья в открытом доступе и распространяется в соответствии с лицензией "Creative Commons" (http://creativecommons.org/licenses/by/3.0/rs/). 